[11C]-choline is an effective PET tracer used for imaging of neoplastic lesions and metastases of the prostate cancer. However, its production can be a challenge for manufacturers, as it has not yet been described in Polish or European pharmacopoeia. In this study the technical aspects of [11C]-choline production are described and detailed process parameters are provided. The quality control procedures for releasing [11C]-choline as solutio iniectabilis are also presented. The purity and quality of the radiopharmaceutical obtained according to the proposed method were find to be high enough to safely administrate the radiopharmaceutical to patients. Application of an automated synthesizer makes it possible to carry out the entire process of [11C]-choline production, isolation and purification within 20 minutes. It is crucial to maintain all aspects of the process as short as possible, since the decay half-time of carbon-11 is 20.4 minutes. The resulting radiopharmaceutical is sterile and pyrogen-free and of a high chemical, radiochemical, and radionuclide purity proved by chromatographic techniques. The yield of the process is up to $20 \%$. [11C]-choline PET scanning can be used as accurate and effective diagnostic tool in all centers equipped with [11C]-target containing cyclotron.

Contemp Oncol (Pozn) 2016; 20 (3): 229-236 DOI: $10.5114 /$ wo.2016.61566

\section{Synthesis, isolation and purification of [11C]-choline}

\author{
Marcin Szydło ${ }^{1}$, Michał Jadwiński ${ }^{1}$, Agnieszka Chmura ${ }^{1}, K_{\text {Kamil Gorczewski }}{ }^{1}$, \\ Maria Sokót ${ }^{2}$
}

${ }^{1}$ PET Diagnostics Department, Maria Sklodowska-Curie Memorial Cancer Centre and Institute of Oncology, Gliwice Branch, Poland

2Department of Medical Physics, Maria Sklodowska-Curie Memorial Cancer Centre and Institute of Oncology, Gliwice Branch, Poland

\section{Introduction}

Medical imaging using the positron emission tomography method has been proven to be a unique tool in cancer diagnosis due to its sensitivity and specificity [1]. Despite being a relatively new diagnostic method in Poland, PET's popularity continues to grow due to the application of a wide range of possible PET tracers, also outside the oncology field.

In PET imaging, [ $\left.{ }^{18} \mathrm{~F}\right]-\mathrm{FDG}$ (fluorodeoxyglucose) was one of the first tracers described, and it is still the most popular one due to its high sensitivity to neoplastic processes. However, its value is limited in diagnosing cancers characterised by low glucose metabolism, for example prostate cancer [2], the most commonly diagnosed cancer among men and the second (after lung cancer) most common malignant cause of death. Beside Fluorine-18, tracers containing Gallium-68 [3, 4], lodine-124 [5], or Carbon-11 are also widely used. The carbon atoms are present in the construction of almost all biologically active compounds. Therefore, the use of isotope Carbon-11 allows the construction of an extremely rich group of PET tracers. $\left.{ }^{[1} \mathrm{C}\right]-\mathrm{me}$ thionine, $\left[{ }^{11} \mathrm{C}\right]$-acetate, and $\left[{ }^{11} \mathrm{C}\right]$-choline are the most popular ones [6-8]. However, $\left[{ }^{11} \mathrm{C}\right]$-DASB used in imaging of serotonin transporters (SERT) [9] and $\left[{ }^{11} \mathrm{C}\right]$-Raclopride, which is applied in imaging of the post-synaptic receptors of dopamine [10], and many others [11] are worth noting.

Increased phospholipid synthesis and increased uptake of choline have been associated with cell proliferation and the transformation process that occurs in tumour cells. It happens because choline is involved in the synthesis of structural components of cell membranes, as well as modulation of trans-membrane signalling [12].

$\left[{ }^{11} \mathrm{C}\right]$-choline tracers were revealed to be especially useful in early-state prostate cancer diagnostic imaging [13]. Although imaging with this tracer is a high-cost procedure due to the short half-life of this agent and the requirement of its on-site production, choline PET/CT can detect both bone and soft-tissue metastases with a single examination, making it cheaper.

This study was focused on the key stages of the synthesis and quality control of $\left[{ }^{11} \mathrm{C}\right]$-choline. The use of this tracer in PET imaging is very vast. However, its production can be a challenge for manufacturers because it has not yet been described in Polish or European pharmacopoeia.

It is also worth noting that in $2012\left[{ }^{11} \mathrm{C}\right]$-choline was approved by the U.S. Food \& Drug Administration (FDA) for clinical use.

\section{Material and methods}

The procedure of $\left[{ }^{11} \mathrm{C}\right]$-choline production fulfils the Guidelines on Good Radiopharmacy Practice issued by the Radiopharmacy Committee of the EANM (European Association of Nuclear Medicine) [14]. Its general aspects, provided by Hockley et al. [15], have been developed and presented in detail together with the quality-assurance procedures. 
Isotope production

The starting point of the production of Carbon-11-labelled radiopharmaceuticals is the ${ }^{14} \mathrm{~N}(\mathrm{p}, \alpha){ }^{11} \mathrm{C}$ nuclear reaction [16] - it takes place on the gaseous target of the Cyclone 18/9 (IBA) cyclotron with protons of $18 \mathrm{MeV}$ energy.

The radioisotope is produced by proton irradiation (target current $=38 \mu \mathrm{A}$ ) of a gas $\mathrm{N}_{2} / \mathrm{O}_{2}$ mixture (the nitrogen target gas contains $0.5 \%$ oxygen, filling pressure equals 19 bar) with the proton beam energy of $18 \mathrm{MeV}$. The in-target activity of $\left[{ }^{11} \mathrm{C}\right]-\mathrm{CO}_{2}$ peaks at $20-25$ minutes of beam time, yielding $68 \mathrm{GBq}$.

\section{Synthesis of $\left[{ }^{11} \mathrm{C}\right]$-methyl iodide}

The $\left[{ }^{11} \mathrm{C}\right]-\mathrm{CO}_{2}$ produced in a cyclotron is trapped on the molecular sieve of the synthesis module. To increase their efficiency, the molecular sieves are conditioned. This process involves removing moisture from the filling volume by heating it to a temperature of $250^{\circ} \mathrm{C}$ and simultaneously purging with nitrogen. The first conditioning should last 60 minutes, and before each subsequent use of the molecular sieves, the conditioning can be shortened to
20 minutes. The Bioscan synthesis module is used for preparation of $\left[{ }^{11} \mathrm{C}\right]$-choline. It consists of the Mel-PLUS ${ }^{\mathrm{TM}}$ unit adapted for the synthesis of $\left.{ }^{11} \mathrm{C}\right]$-methyl iodide and the Reform-PLUS ${ }^{\mathrm{TM}}$ unit in which the $\left[{ }^{11} \mathrm{C}\right]-\mathrm{CH}_{3}$ l precursor's synthesis, isolation, purification, and final product collection take place. The modules are installed in hot cells to decrease the operator's exposure to ionising radiation. Since Carbon-11 is produced in the form of a gaseous $\left[{ }^{11} \mathrm{C}\right]$-carbon dioxide, the chamber is adapted to collect potentially radioactive air from inside of the chambers.

The release of $\left.{ }^{11} \mathrm{C}\right]-\mathrm{CO}_{2}$ into the reaction vial is performed identically as the conditioning: by heating the molecular sieves of the Mel PLUS ${ }^{\mathrm{TM}}$ unit to a temperature of $250^{\circ} \mathrm{C}$ for 90 seconds while purging the sieves with a nitrogen gas flow of $15 \mathrm{ml} / \mathrm{min}$. Using a vial, $\left.{ }^{11} \mathrm{C}\right]-\mathrm{CO}_{2}$ is reduced to methanol with $\mathrm{LiAlH}_{4}$ in a tetrahydrofuran (THF) environment. After the evaporation of THF from the reaction mixture, a $57 \%$ solution of hydriodic acid is added to the reaction vial - it reacts with $\left[{ }^{11} \mathrm{C}\right]-\mathrm{MeOH}$ and forms $\left.{ }^{[11} \mathrm{C}\right]-\mathrm{CH}_{3} \mathrm{I}[17]$. Figure 1 shows the radioactivity and oven temperature changes taking place during the subsequent stages of the $\left[{ }^{11} \mathrm{C}\right]-$ Mel synthesis.

\begin{tabular}{|c|l|}
\hline A & Begin CO2 Trapping \\
\hline B & Sieve Oven On \\
\hline C & Begin CO2 Release \\
\hline D & Sieve Oven Off \\
\hline E & Begin THF \\
\hline F & Mel Output Opened \\
\hline G & Begin Mel Distilation \\
\hline H & End Mel Distillation \\
\hline I & Start Wash 1 \\
\hline J & Start Wash 2 \\
\hline K & Start Wash 3 \\
\hline L & Start N2 Drying \\
\hline
\end{tabular}

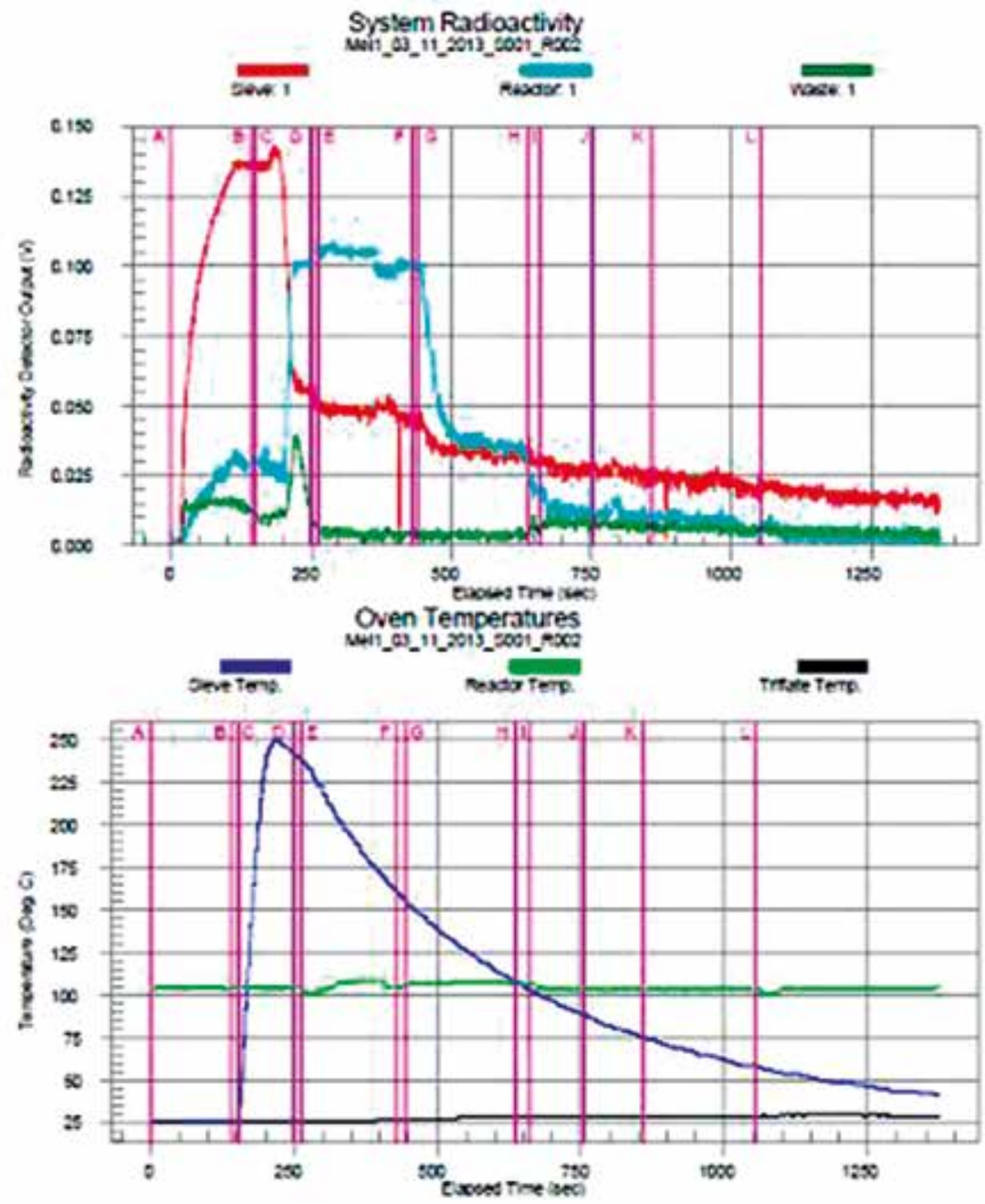

Fig. 1. System activity and oven temperature changes during Mel synthesis 


\section{$\left[{ }^{11} \mathrm{C}\right]-\mathrm{CH}_{3}$ I distillation and reaction with the precursor}

The $\left[{ }^{11} \mathrm{C}\right]$-methyl iodide distilled from the Mel PLUS ${ }^{\mathrm{TM}}$ unit is then transported into the vial by a constant flow of nitrogen $(10 \mathrm{ml} / \mathrm{min})$. The vial, which is a part of the ReFORM PLUS ${ }^{\text {TM }}$ kit, contains the precursor, dimethylaminoethanol (DMAE) dissolved in dimethylformamide (DMF) in the ratio of $10 \mu \mathrm{l}$ DMAE : $200 \mu \mathrm{l}$ DMF. The reaction of $\left[{ }^{11} \mathrm{C}\right]-\mathrm{CH}_{3}$ I with DMAE takes place almost instantaneously at room temperature, according to the formula [18]:

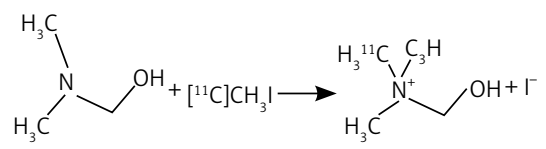

Competitive reactions with water, saline, or ethanol may also take place because methyl iodide is highly reactive. Such reactions are facilitated by the diffusion of the mentioned reagents into the ReFORM PLUS ${ }^{\mathrm{T} M}$ tubing assembly. Thus, the valves of the ReFORM PLUS ${ }^{\mathrm{TM}}$ kit should be carefully checked and closed. The reagents may be loaded after double-checking the valves.

\section{Isolation and purification of $\left[{ }^{11} \mathrm{C}\right]$-choline}

The isolation and purification process is a four-step procedure conducted by the ReFORM PLUS ${ }^{\mathrm{TM}}$ unit. First, $1 \mathrm{ml}$ of ethanol is added to the reaction vial to homogenise the mixture. Afterward, the whole mixture is extracted to solid phase on a cation exchange resin (Sep-Pack Accell Plus CM; Waters [8]). As the ionic compound, $\left[{ }^{11} \mathrm{C}\right]$-choline is captured by the SPE column, and the remaining components of the reaction mixture are removed. To confirm the proper purification of the product, especially from the insoluble substances present in organic solvents, the SPE column should be washed twice with $5 \mathrm{ml}$ of water. The final product is released from the SPE column using $0.9 \%$ saline solution and collected in a sterile, pyrogen-free vial with septum enclosure after the previous filtration on a 0.22- $\mu \mathrm{m}$ membrane sterile filter. Figure 2 shows the changes of the system radioactivity during the reformulation process.

In our first attempts at the synthesis of $\left[{ }^{11} \mathrm{C}\right]$-choline a SPE SCX Maxi-Clean (Alltech) column was used instead of a Sep-Pack Accell Plus CM. However, the product could not be released from SCX Maxi-Clean cartridge with saline.

In a series of eleven subsequent approaches $\left[{ }^{11} \mathrm{C}\right]$-choline was obtained with the yield up to $20 \%$, as measured relative to the activity of $\left[{ }^{11} \mathrm{C}\right]-\mathrm{CO}_{2}$ captured on molecular sieves.

The synthesised and purified product is a sterile, colourless solution of $\mathrm{pH}$ 7.5-8.5. Its sterility is determined by an accredited laboratory.

\section{Quality control}

The Polish and European Pharmacopoeia do not provide any guidelines on $\left[{ }^{11} \mathrm{C}\right]$-choline quality control. However, some quality parameters can be customised on the basis of the general information from the pharmacopoeial chapters [19]: Potentiometric determination of $\mathrm{pH}$ (2.2.3), Gas chromatography (2.2.28), Identification and control of residual solvents (2.4.24), Sterility (2.6.1), and Bacterial endotoxins (2.6.14).

The quality control procedures based on the mentioned chapters are described in the subsequent points.

\section{Chemical and radiochemical purity}

The chemical and radiochemical purity are controlled using UHPLC apparatus DIONEX Ultimate 3000 with UVVIS DAD, scintillation detector, and Corona CAD.

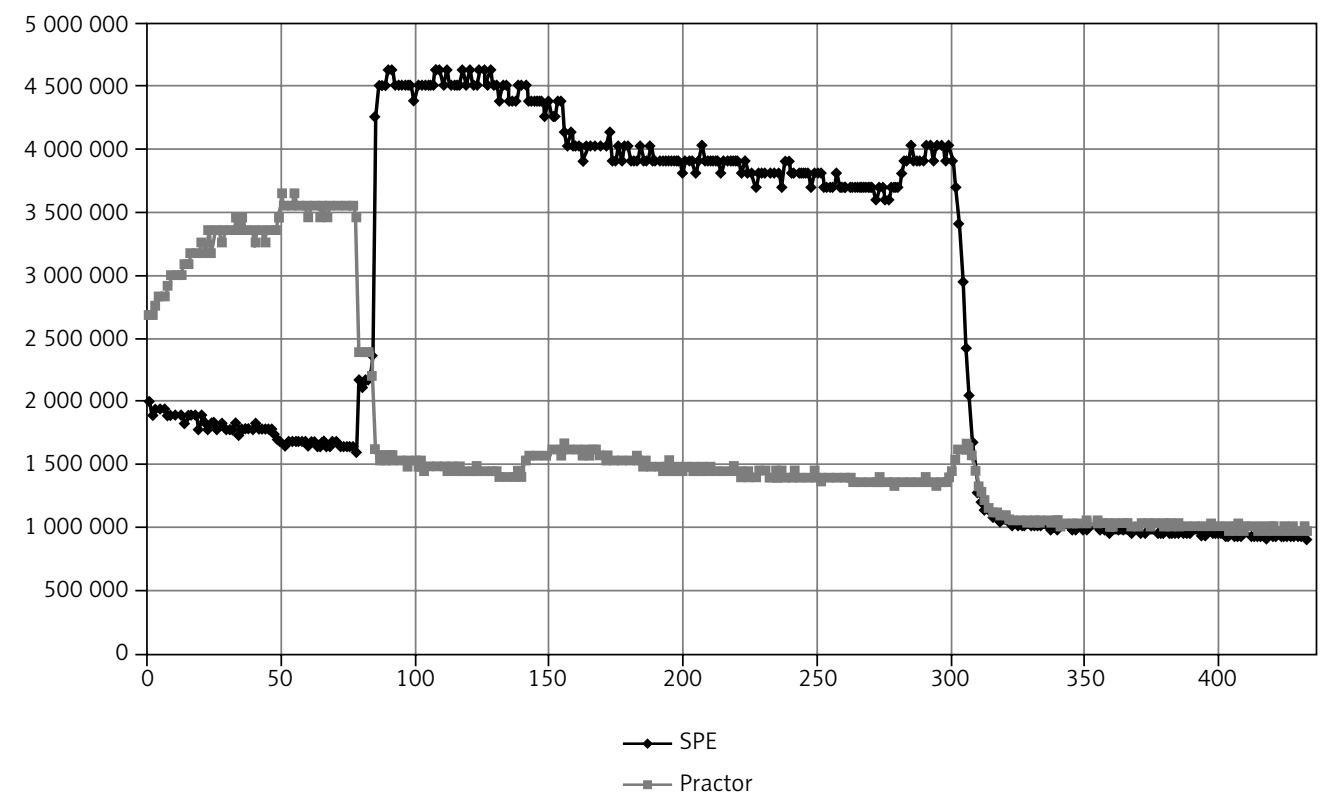

Fig. 2. System radioactivity changes during the reformulation process 
This study applies two analytical approaches to serve different application purposes. The first method, described by Boschi et al. [20], uses a phase-reversed C18 column ( Bondapack ${ }^{\circledR}$ C18; $3.9 \times 300$ mm; Waters) and a mobile phase, which is a mixture of $3 \mathrm{mM}$ sodium 2-naphthalenesulfonate (in place of 2-naphthalenesulfonic acid) with the addition of $1 \mathrm{mM} \mathrm{H}_{3} \mathrm{PO}_{4}$ with a flow rate of $1 \mathrm{ml} / \mathrm{min}$.

The second approach is especially suitable for quality assurance, impurity analysis, and trace-level residue analysis, and it suits qualitative, confirmative, and semiquantitative applications. The HPLC method, benefiting from an Acclaim ${ }^{\circledR}$ Trinity ${ }^{\top M}$ trimode column, is able to separate cations, anions, and neutral species in a single run. It is based on the method described by Crafts et al. [21] and combines an Acclaim Trinity P1 column $(3.0 \times 50$ mm; DIONEX) - a high-purity silica column designed for pharmaceutical applications - and three mobile phases (with flow rate $0.7 \mathrm{ml} / \mathrm{min}): 200 \mathrm{mM}$ of ammonium acetate $(\mathrm{pH}=4)$ $(\mathrm{A})$, distilled water $(\mathrm{B})$, and acetonitrile $(\mathrm{C})$ with gradients of $5 \%$ (A), $35 \%$ (B), and $60 \%$ (C) (gradient time from 0 to $10 \mathrm{~min}$ ) and of $40 \%$ (B) and $60 \%$ (C) (gradient time from 10 to $25 \mathrm{~min}$ ).

The radiochemical detection was carried out using a scintillation detector with a CsI crystal.

Both analytical methods identify $\left[{ }^{11} \mathrm{C}\right]$-choline. However, the first technique suffers from a detection limit that is too high, although the resolution of the choline signal detected at the retention time of 9.5 minutes (on the UV-VIS detector tuned to the wavelength of $297 \mathrm{~nm}$ ) is satisfactory (Fig. 3). In the second method (the detection performed using charged aerosol detector - Corona CAD) the retention time is 1.2 minutes and the resolution is worse, but the detection limit is over 10-times better (Fig. 4).

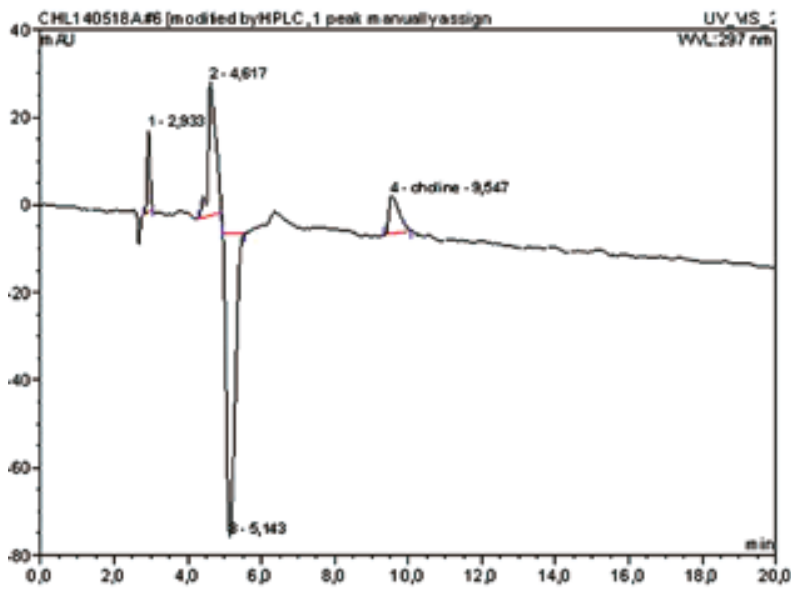

Fig. 3. Chromatogram of choline chloride method 1

\section{Nuclide identification}

The radionuclide identification was based on the results of gamma radiation energy measurements [22] and the calculation of a radionuclide half-life.

For the positron emitting isotopes - such as Carbon-11 - the energy of the detected gamma quanta should be $511 \mathrm{keV}$, as the positrons annihilate with electrons. The expected half-life of Carbon-11 is 20.4 minutes [23]. The decay properties of Carbon-11 are shown in Table 1.

The gamma-ray spectroscopy was done using RAYTEST MUCHA multichannel analyser with Nal $3 \times 3$ " detector. The $511 \mathrm{keV}$ photons and a sum peak of $1022 \mathrm{keV}$ are observed in the gamma-ray spectrum, thus confirming the positron decay mechanism of the obtained radionuclide, as shown in Fig. 5.

The radiotracer half-life was obtained using calibrated radiometric method and applying an ionisation chamber dose calibrator for the activity measurements. Each activity measurement lasts 15 minutes and is repeated every minute. The radionuclide half-life can be calculated using the following equation [24]:

$T_{1 / 2}=-\ln 2\left(\frac{\mathrm{dt}}{\ln \left(\frac{A_{1}}{A_{0}}\right)}\right)$

where:

dt - time difference, $A_{1}$ - ending activity, and $A_{0}$ - starting activity.

The half-life time equals $20.3 \pm 0.1$ minutes and uniquely identifies the nuclide as Carbon-11.

Table 1. Carbon-11 decay scheme

$\begin{array}{lcccccc}\text { Parent nuclide } & \mathrm{T}_{1 / 2} & \text { Decay mode } & \text { Emax } & \text { Relative intensity } & \mathrm{E} \gamma & \text { Daughter nuclide } \\ { }_{6}^{11} \mathrm{C} & 20.38 \mathrm{~min} & + & 960.2 \mathrm{keV} & 99.759 \% & 511 \mathrm{keV} & { }_{6}^{11} \mathrm{C}\end{array}$




\section{Bacterial endotoxin purity}

The same bacterial endotoxin limit for $\left[{ }^{11} \mathrm{C}\right]$-choline was accepted as $\left[{ }^{18} \mathrm{~F}\right]-\mathrm{FDG}$, i.e. < 175 EU/dose; maximum dose $10 \mathrm{ml}$ per patient [25].

The bacterial endotoxin test was performed using Endosafe ${ }^{\circledR}$-PTS ${ }^{\text {TM }}$ (Charles River) apparatus and the kinetic chromogenic LAL-test method [26] was applied, in accordance with the European Pharmacopoeia [25].

\section{Residual solvents}

The methodology for organic residual solvents testing was in accord with the pharmacopoeial method [27]. However, some parameters (such as split ratio and total flow rate) were modified by a trial-and-error method, to adjust the procedure to the equipment used in the analysis.

A gas chromatography system equipped with an HP-Innowax column $(30 \mathrm{~m} \times 0.32 \mathrm{~mm}$; film: polyethylene glycol $0.50 \mu \mathrm{m})$ was used. The adjusted parameters were as follows: the volume of sample injection was $1 \mu$ l; split $5.0: 1$ at a total flow of $16 \mathrm{ml} / \mathrm{min}$ with helium as a carrier. The column's oven temperature: $50^{\circ} \mathrm{C}$. Detection was carried out on an FID detector.

\section{Radionuclide purity}

Gamma spectroscopy [28] of the final sample was carried out in a Canberra-Packard gamma spectrometer equipped with a high-purity germanium (HPGe) detector. The spectral measurements were performed two days after the synthesis. The spectrum was measured for 180 minutes to integrate enough counts for high a signal-tonoise ratio $(\mathrm{S} / \mathrm{N})$ and to resolve the spectrum. The sample volume should be at least $1 \mathrm{ml}$. The gamma spectrum, shown in Fig. 6, was analysed using Genie 2000 software and the radionuclide content was determined to be below $0.1 \%$.

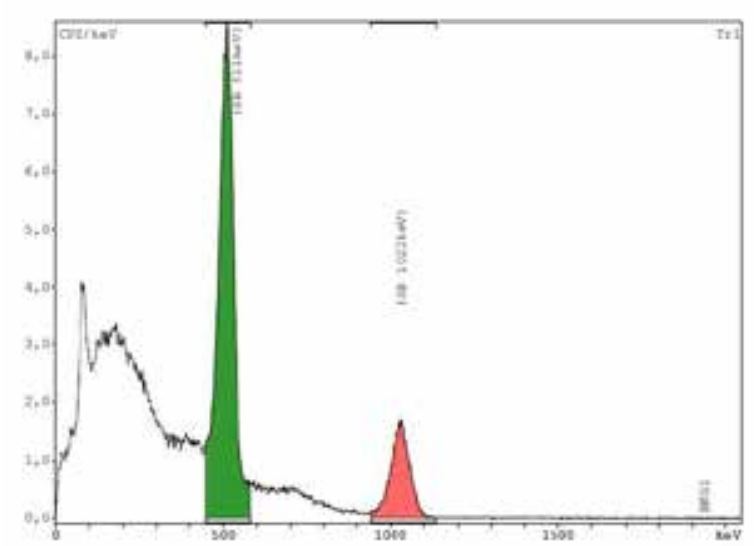

Fig. 5. Gamma-ray spectrum of Carbon-11

\section{Results}

The highest activity output of Carbon-11 isotope produced in a cyclotron target took place in the first minute of irradiation. During the first minute of the process the Carbon-11 radioactivity reached about $3.7 \mathrm{GBq}$. A target irradiation for 25 minutes yielded about 68.45 GBq of Carbon-11 radioactivity. Saturation of the target was obtained after about two hours and the activity gained was $110 \mathrm{GBq}$. Then, the activity yield decreased - this was due to saturation of the target material and the decay processes of Carbon-11.

Within five minutes, the target was discharged and the product $-\left[{ }^{11} \mathrm{C}\right]-\mathrm{CO}_{2}$ - was trapped on the molecular sieves. The operating time of the Mel PLUS ${ }^{\mathrm{TM}}$ unit, from the start of heating of the molecular sieves until the end of the $\left[{ }^{11} \mathrm{C}\right]$-methyl iodide distillation was approximately 11 minutes, and the yield of the released $\left[{ }^{11} \mathrm{C}\right]-\mathrm{CO}_{2}$ from the molecular sieves was between 85 and 90\%. Reformulation and collection of the product in the final product vial took

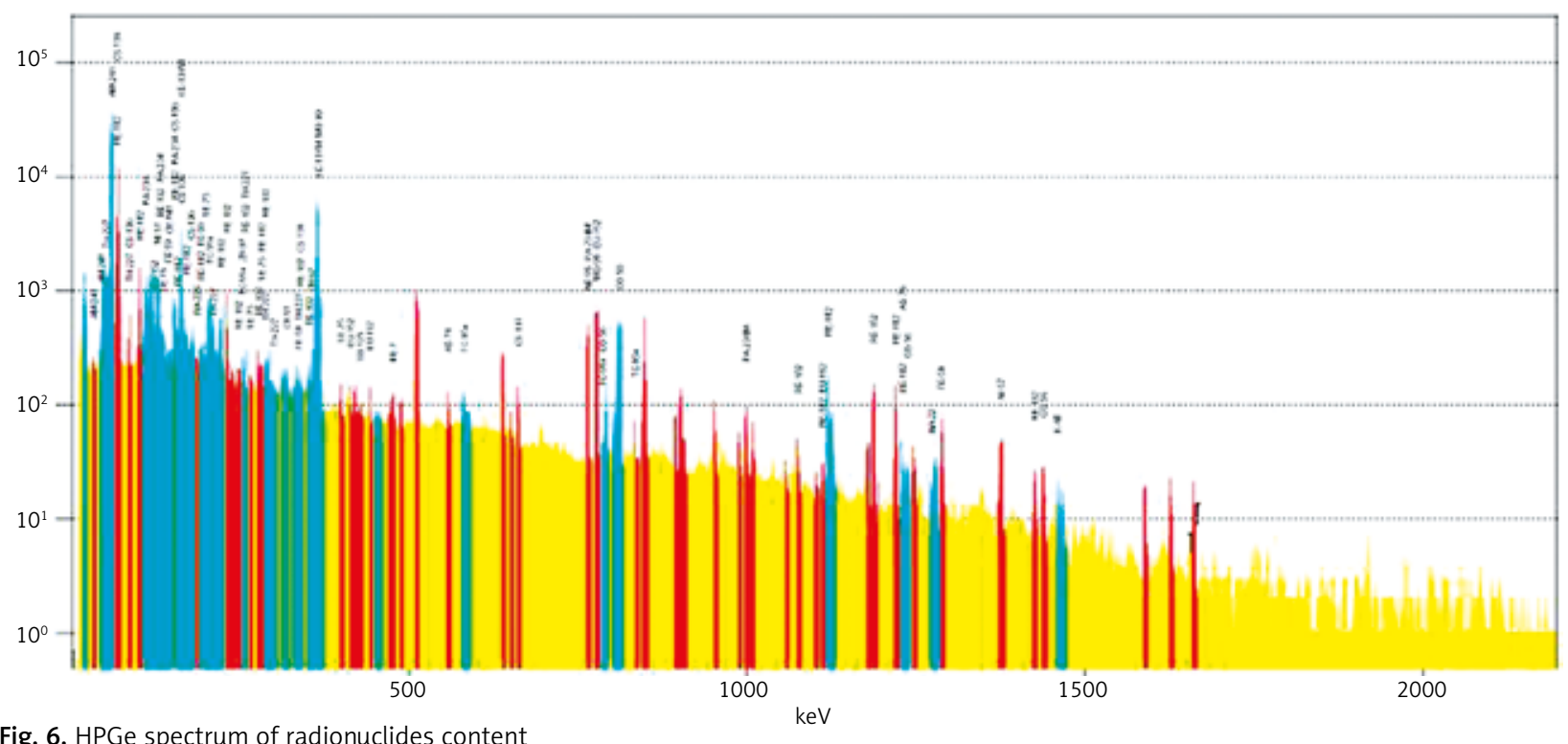

Fig. 6. HPGe spectrum of radionuclides content 
six minutes. Thus, the total time required for production, purification, and packaging of $\left[{ }^{11} \mathrm{C}\right]$-choline equaled approximately a half-life time of Carbon-11, with a yield of up to $20 \%$, as calculated on the basis of activity. In practice, when starting from an initial activity of $65 \mathrm{GBq}$, it was possible to obtain $14 \mathrm{GBq}$ of $\left[{ }^{11} \mathrm{C}\right]$-choline in a form of sterile, pyrogen-free isotonic solution.

Table 2 summarises the quality control data of the final product (its chemical, radiochemical, radionuclidic, and biological purities). The results confirm the batch-to-batch reproducibility of the production process and identify a radionuclide as Carbon- 11 by a match of measured decay characteristics to the listed values. The radiochemical purity, determined by liquid chromatography method, exceeded $99 \%$, and the amount of radionuclide impurities was less than $0.1 \%$. The levels of ethanol and dimethylformamide meet the pharmacopoeia requirements [29], as confirmed by gas chromatography.

Application of Corona CAD detector enhances the signal-to-noise ratio and chemical purity of the synthesised $\left.{ }^{[11} \mathrm{C}\right]$-choline is at least $98 \%$.

\section{Discussion}

Radiopharmaceuticals are only supplied for use in patients if they have been correctly processed, checked and stored in accordance with the defined procedures and released by a competent person. Thus, the quality control procedure is an important part of the production process. Control operations involve chemical purity control, radiochemical purity control, nuclide identification, bacterial endotoxin purity control, and residual solvent detection.

Chemical purity of radiopharmaceuticals refers to the amount of undesirable chemical species present. Chemical impurities include all nonradioactive substances that can either affect the radiolabeling process or directly produce adverse biological effects [30].

Radiochemical purity is defined as the percentage of the total radioactivity present in the desired chemical form in a radioactive pharmaceutical [31]. This kind of purity is a crucial issue in a diagnostic PET image interpretation, especially in case of short-lived radiopharmaceuticals - an unacceptable radiochemical purity can lead to radiopharmaceutical unspecific uptake, which may result in irradiation of critical organs and false diagnosis. The described $\left[{ }^{11} \mathrm{C}\right]$-choline manufacturing process allows eight doses of the radionuclide to be prepared for clinical applications, whereas total time required to produce one batch of the radiopharmaceutical, including quality control, is approximately one hour, which allows to produce three series per working day with a total number of 24 doses of $\left[{ }^{11} \mathrm{C}\right]$-choline.

Another radiotracer with a similar use as $\left[{ }^{11} \mathrm{C}\right]$-choline is $\left[{ }^{18} \mathrm{~F}\right]$-fluoromethylcholine, and its manufacturing processes is described elsewhere [8]. Due to $\left[{ }^{18} \mathrm{~F}\right]$-labelling, the halflife of $\left[{ }^{18} \mathrm{~F}\right]$-fluoromethylcholine is longer (109 minutes vs. 20 minutes in the case of $\left[{ }^{11} \mathrm{C}\right]$ ), whereas the $\left[{ }^{18} \mathrm{~F}\right]$ positron range is shorter [32]. The longer half-life makes it possible to distribute the product away from the manufacturing site. However, the $\left[{ }^{11} \mathrm{C}\right]$-choline is preferred for prostate PET/CT imaging due to better distribution and higher assimilation of this tracer in the patient's body as compared to $\left[{ }^{18} \mathrm{~F}\right]$-fluoromethylcholine $[33,34]$ - the advantage of the latter is its nearly four-times longer half-life, which makes shipping possible and facilitates commercial availability of the choline containing tracer.

The purity and quality of the obtained radiopharmaceutical are high enough to safely administer it to patients. The production is also safe for the operator - due to the

Table 2. Experimental quality control data

\begin{tabular}{|c|c|c|c|c|c|c|}
\hline \multicolumn{7}{|c|}{ QUALITY CONTROL } \\
\hline Test & $\begin{array}{l}\text { Acceptance } \\
\text { criteria }\end{array}$ & Batch 1 & Batch 2 & Batch 3 & Batch 4 & Batch 5 \\
\hline $\mathrm{pH}$ & $4.5-8.5$ & 8.23 & 8.16 & 8.27 & 8.19 & 8.29 \\
\hline Appearance & Clear, colourless & $\begin{array}{l}\text { Clear, } \\
\text { colourless }\end{array}$ & Clear, colourless & Clear, colourless & Clear, colourless & $\begin{array}{l}\text { Clear, } \\
\text { colourless }\end{array}$ \\
\hline $\mathrm{EtOH}$ & $\leq 5000 \mu \mathrm{g} / \mathrm{ml}$ & $4251.36 \mu \mathrm{g} / \mathrm{ml}$ & $3017.87 \mu \mathrm{g} / \mathrm{ml}$ & $3981.82 \mu \mathrm{g} / \mathrm{ml}$ & 3964.24 Mg/ml & $3682.47 \mu \mathrm{g} / \mathrm{ml}$ \\
\hline DMF & $\leq 880 \mu \mathrm{g} / \mathrm{ml}$ & $717.62 \mu \mathrm{g} / \mathrm{ml}$ & $730.56 \mu \mathrm{g} / \mathrm{ml}$ & $662.97 \mu \mathrm{g} / \mathrm{ml}$ & $877.21 \mu \mathrm{g} / \mathrm{ml}$ & $710.29 \mu \mathrm{g} / \mathrm{ml}$ \\
\hline DMAE & $10 \mu \mathrm{g} / \mathrm{ml}$ & $<7 \mu \mathrm{g} / \mathrm{ml}$ & $<7 \mu \mathrm{g} / \mathrm{ml}$ & $<7 \mu \mathrm{g} / \mathrm{ml}$ & $<7 \mu \mathrm{g} / \mathrm{ml}$ & $<7 \mu \mathrm{g} / \mathrm{ml}$ \\
\hline $\begin{array}{l}\text { Radiochemical } \\
\text { purity }\end{array}$ & $\begin{array}{l}\geq 95 \% \text { of }\left[{ }^{11} \mathrm{C}\right]- \\
\text { choline }\end{array}$ & $99.09 \%$ & $99.36 \%$ & $99.20 \%$ & $99.32 \%$ & $99.30 \%$ \\
\hline $\begin{array}{l}\text { Gamma-ray } \\
\text { identification }\end{array}$ & $511 \pm 10 \mathrm{KeV}$ & $511 \mathrm{keV}$ & $512 \mathrm{keV}$ & $514 \mathrm{keV}$ & $514 \mathrm{keV}$ & $510 \mathrm{keV}$ \\
\hline Radionuclidic purity & $\geq 99.9 \%$ & $>99.9 \%$ & $>99.9 \%$ & $>99.9 \%$ & $>99.9 \%$ & $>99.9 \%$ \\
\hline Half-life & 19.9-20.9 min & $20.3 \mathrm{~min}$ & $20.3 \min$ & $20.3 \mathrm{~min}$ & $20.4 \mathrm{~min}$ & $20.2 \mathrm{~min}$ \\
\hline Bacterial endotoxin & $\begin{array}{c}\text { Ph. Eur. } \\
\text { Conform } \\
(<17.5 \mathrm{lU} / \mathrm{ml})\end{array}$ & $<10 \mathrm{IU} / \mathrm{ml}$ & $<10 \mathrm{IU} / \mathrm{ml}$ & $<10 \mathrm{IU} / \mathrm{ml}$ & $<10 \mathrm{IU} / \mathrm{ml}$ & $<10 \mathrm{IU} / \mathrm{ml}$ \\
\hline Sterility & $\begin{array}{l}\text { Ph. Eur. } \\
\text { Conform }\end{array}$ & Sterile & Sterile & Sterile & Sterile & Sterile \\
\hline
\end{tabular}


short half-life of Carbon-11, radiological contamination in the hot cell is reduced to a safe level within two hours.

$\left[{ }^{11} \mathrm{C}\right]$-choline-PET/CT may offer new hope to patients with prostate cancer and lymph node metastasis because current imaging modalities (including transrectal ultrasound, MRI, CT, and bone scan) demonstrate poor performance in the diagnosis and staging of this disease. $\left[{ }^{11} \mathrm{C}\right]$-choline seems also to open a promising path for the study of genetic disorders involving metabolic alternations of choline-containing metabolites [35].

\section{Conclusions}

The described $\left.{ }^{[11} \mathrm{C}\right]$-choline manufacturing process allows eight doses of the radionuclide to be prepared for clinical applications.

The total time required to produce one batch of the radiopharmaceutical, including quality control, is approximately one hour, which allows the production of three series per working day with a total number of 24 doses of $\left[{ }^{11} \mathrm{C}\right]$-choline.

The radiopharmaceutical purity and its quality are high enough to safely administer the radiopharmaceutical to patients. The production is also safe for the operator.

All cyclotron-PET centres equipped with a $\left[{ }^{[1} \mathrm{C}\right]$-target containing cyclotron can consider using $\left[{ }^{[11} \mathrm{C}\right]$-choline because it has better diagnostic properties over Fluorine-18 analogue.

The authors declare no conflict of interest.

\section{References}

1. Jones T. The role of positron emission tomography within the spectrum of medical imaging. Eur J Nucl Med 1996; 23: 207-11.

2. Jadvar H. Molecular imaging of prostate cancer with ${ }^{18} \mathrm{~F}$-fluorodeoxyglucose PET. Nat Rev Urol 2009; 6: 317-23.

3. Afshar-Oromieh A, Malcher A, Eder M, et al. PET imaging with a $\left[{ }^{68} \mathrm{G}\right.$ a]gallium-labelled PSMA ligand for the diagnosis of prostate cancer: biodistribution in humans and first evaluation of tumour lesions. Eur I Nucl Med Mol Imaging 2013; 40: 486-95.

4. Al-Nahhas A, Win Z, Szyszko T, Singh A, Nanni C, Fanti S, Rubello D. Gallium-68 PET: A New Frontier in Receptor Cancer Imaging Anticancer Rerearch 2007; 27: 4087-94.

5. Chacko AM, Divgi CR. Radiopharmaceutical chemistry with iodine-124: a non-standard radiohalogen for positron emission tomography. Med Chem 2011; 7 (5 Suppl): 395-12.

6. Comar D, Carton JD, Maziere M, Marazano C. Labeling and Metabolism of Methionine-Methyl-1ㄷ. Eur J Nucl Med 1976; 1: 11-4.

7. Soloviev D, Tamburella C. Captive solvent $\left[{ }^{11} \mathrm{C}\right]$ acetate synthesis In GMP conditions. Appl Radiat Isotopes 2006; 64: 995-1000.

8. Shao X, Hockley BG, Hoareau R, Schnau PL, Scott PJH. Fully automated preparation of $\left[{ }^{11} \mathrm{C}\right]$ choline and $\left[{ }^{18} \mathrm{~F}\right]$ fluoromethylcholine using TracerLab synthesis modules and facilitated quality control using analytical HPLC. Appl Radiat Isotopes 2011; 69: 403-9.

9. Meyer JH, Wilson AA, Sagrati S, et al. Serotonin transporter occupancy of five selective serotonin reuptake inhibitors at different doses: an $\left.{ }^{11} \mathrm{C}\right] \mathrm{DASB}$ positron emission tomography study. Am J Psychiatry 2004; 161: 826-35.

10. Kapur S, Remington G, Jones C, Wilson A, Dasilva J, Houle D, Zipursky R. High levels of dopamine D-2 receptor occupacy with lowdose haloperidol treatment: A PET study. Am J Psychiatry 1996; 153: 948-50.
11. Shao X, Hoareau R, Runkle AC, Tluczek LJM, Hockley BG, Henderson BD, Scott PJH. Highlighting the versatility of the Tracerlab synthesis modules. Part 2: fully automated production of $\left[{ }^{11} \mathrm{C}\right]$-labeled radiopharmaceuticals using a Tracerlab $F_{\text {c.pro }}$. J Label Compd Radiopharm 2011; 54: 819-38.

12. de Jong IJ, Pruim J, Elsinga PH, Vaalburg W, Mensink HJ. Preoperative Staging of Pelvic Lymph Nodes in Prostate Cancer by ${ }^{11} \mathrm{C}$-Choline PET. J Nucl Med 2003; 44 (3 Suppl): 331-35.

13. Yamaguchi T, Lee J, Uemura H, et al. Prostate cancer: a comparative study of ${ }^{11} \mathrm{C}$-choline PET and MR imaging combined with proton MR spectroscopy. Eur J Nucl Med Mol Imaging 2005; 32 (7 Suppl): 742-48.

14. Elsinga P, Todde S, Penuelas I, Meyer G, Farstad B, Faviere-Chauvet A, Mikolajczak R, et al. Guidance on current good radiopharmacy practice (cGRPP) for small-scale preparation of radiopharmaceuticals. Eur J Nucl Med Mol Imaging 2010; 37 (5): 1049-62.

15. Scott PJH, Hockley BG. Radiochemical Syntheses Vol. 1: Radiochemicals for Positron Emission Tomography. In: Hockley, BG, Henderson B, Shao X. Synthesis of $\left[{ }^{11} \mathrm{C}\right]$-Choline Chloride $\left(\left[{ }^{11} \mathrm{C}\right] \mathrm{CHL}\right)$. John Wiley \& Sons 2012; 169-177.

16. Hara T, Yuasa M. Automated synthesis of $\left[{ }^{11} \mathrm{C}\right]$ choline, a positron-emitting tracer for tumor imaging. Appl Radiat Isotopes 1999; 50: 531-33.

17. Marazano C, Maziere M, Berger G, Comar D. Synthesis of methyl iodide- ${ }^{11} \mathrm{C}$ and formaldehyde ${ }^{-11} \mathrm{C}$. Int I Appl Radiat Is 1977; 28 (1-2 Suppl): 49-52.

18. Rosen MA, Jones RM, Yano Y, Budinger TF. Carbon-11 Choline: Synthesis, Purification, and Brain Uptake Inhibition by 2-Dimetylaminoethanol. J Nucl Med 1985; 26: 1424-28.

19. European Pharmacopoeia $-8^{\text {th }}$ edition Vol. 1 and 2. European Directorate for the Quality of Medicines, 2013.

20. Boschi S, Lodi F, Cicoria G, et al. Development of a modular system for the synthesis of PET $\left[{ }^{11} \mathrm{C}\right]$ labeled radiopharmaceuticals. Appl Radiat Isotopes 2009; 67: 1869-73.

21. http://www.dionex.com/en-us/webdocs/87447-PO-IICS-APICounterion-CAD-180ct2010-LPN2610-01.pdf.

22. Hine GJ. Instrumentation In Nuclear Medicine: Vol. 1. In: Hine GJ. Sodium lodine Scintillators. Academic Press Inc 1967; 95-119.

23. Table of physical characteristic of radionuclides mentioned in the European Pharmacopoeia. In: European Pharmacopoeia $-8^{\text {th }}$ edition. Vol. 1. European Directorate for the Quality of Medicines, 2013; 665-673.

24. Serway RA, Jewett JW. Physics for Scientists and Engineers with Moredn Physics, Chapters 39-46. In: Serway RA, Jewett JW. Nuclear Structure. Thomson Learning Inc. 2008; 1380-17.

25. European Pharmacopoeia $-8^{\text {th }}$ edition; monography 1325.

26. http://pharmacyce.unm.edu/nuclear program/freelessonfiles/ Vol14Lesson5.pdf.

27. Gas chromatography. In European Pharmacopoeia $-8^{\text {th }}$ edition Vol. 1. European Directorate for the Quality of Medicines, 2013; 43-45.

28. Zappata F. Handbook for the Assessment of Soil Erosion and Sedimental Using Environmental Radionuclides. In: Wallbrink PJ, Walling DE, He Q. Radionuclides Measurement Using HPGe Gamma Spectrometry. Springer 2003; 67-96.

29. Identification and control of residual solvents. In European Pharmacopoeia $-8^{\text {th }}$ edition Vol. 1. European Directorate for the Quality of Medicines 2013; 141-145.

30. Schwarz SW, Anderson CJ. Radiochemistry and radiopharmacology. In: Christian PE, Bernier D, Langan JK, eds. Nuclear Medicine and PET Technology and Techniques, $5^{\text {th }}$ ed., Mosby, St. Louis 2004; 137-183.

31. Mahoney DW, McGough CG. Alternative Radiochemical Purity Testing Procedures for the Compounded Radiopharmaceuticals Approved from 1988-Washington, DC. AphA. 1998.

32. DeGrado T, Baldwin S. Synthesis and evaluation of (18)F-labeled choline analogs as oncologic PET tracers. J Nucl Med 2001; 42: 1805-14.

33. Umbehr MH, Müntener M, Hany T, Sulser T, Bachmann LM. The Role of $\left[{ }^{11} \mathrm{C}\right]$-Choline and $\left[{ }^{18} \mathrm{~F}\right]$-Fluorocholine Positron Emission Tomography (PET) and PET/CT in Prostate Cancer: A Systematic Review and Meta-analysis. Eur Urol 2013; 64 (1 Suppl): 106-17. 
34. Picchio $M$, Berardi $G$, Fodor $\mathrm{A}$, et al. ${ }^{11} \mathrm{C}$-Choline PET/CT as a guide to radiation treatment planning of lymph-node relapses In prostate cancer patients. Eur J Nucl Med Mol Imaging 2014; 41: 127079

35. Małdyk J, Rybczyńska J, Piotrowski D, Kozielski R. Evaluation of calretinin immunohistochemistry as an additional tool in confirming the diagnosis of Hirschsprung disease. Pol J Pathol 2014; 65: 34-9.

\section{Address for correspondence}

\section{Marcin Szydto}

PET Diagnostic Department

Maria Sklodowska-Curie Memorial Cancer Center -

Institute of Oncology

Branch in Gliwice

Wybrzeże Armii Krajowej 15

44-101 Gliwice, Poland

Submitted: 25.09.2015

Accepted: $\quad 30.11 .2015$ 